\title{
IHTEPB'Ю
}

\section{ІНТЕРВ'Ю КАНДИДАТІВ СІЛЬСЬКОГОСПОДАРСЬКИХ НАУК, ПРОВІДНИХ НАУКОВИХ СПІВРОБІТНИКІВ ВІДДІЛУ СЕЛЕКЦІЇ ІНСТИТУТУ ЗРОШУВАНОГО ЗЕМЛЕРОБСТВА НАЦІОНАЛЬНОÏ АКАДЕМІЇ АГРАРНИХ НАУК УКРАЇНИ ГАЛИНИ БАЗАЛІЙ ТА ЛЮДМИЛИ УСИК СТАН ТА ПЕРСПЕКТИВИ СТВОРЕННЯ СОРТІВ ПШЕНИЦІ ДЛЯ ЗРОШЕННЯ В ІНСТИТУТІ ЗРОШУВАНОГО ЗЕМЛЕРОБСТВА}

В Україні пшениця - головна національна культура, її посівні площі (5,5-6,5 млн га, в окремі роки і більше) становлять близько $40 \%$ загальної площі зернових. Основні площі озимої пшениці розміщені у Степовій і Лісостеповій екологічних зонах України, а питома вага зерна у загальних зборах займає до $70 \%$.

Сортові ресурси озимої м'якої пшениці величезні. У реєстрі сортів рослин України на 2021 рік 549 сортів, у тому числі для використання у Степовій зоні України 317.

Селекціонерами Інституту зрошуваного землеробства створено високоврожайні, досить зимостійкі, посухостійкі сорти пшениці озимої, які в умовах Півдня України здатні забезпечувати врожайність на зрошуваних полях 9,0-12,0 т/га, на неполивних по кращих попередниках - 4,0-6,0 т/га.

Вивчена генетична природа багатьох кількісних ознак і властивостей у сортах пшениці, розроблена фізіолого-генетична модель сортів пшениці для Півдня України і принципи трансгресивної селекції на врожайність і адаптацію. Уперше для виробництва зерна на зрошуваних землях Півдня України розроблена науково обґрунтована модель високопродуктивного сорту пшениці, створені нові перспективні сорти, конкурентоспроможні, здатні забезпечити одержання сталих урожаїв високоякісного зерна в посушливих умовах Степової зони Півдня України.

Натепер у Державному реєстрі сортів рослин України зареєстровано 18 сортів пшениці озимої - 15 сортів пшениці м'якої озимої, 3 сорти пшениці твердої озимої $(3,7 \%)$ селекції Інституту зрошуваного землеробства. У більшості з них урожайний потенціал перевищує 10,0 т/га. Новостворені сорти I33 у держсортовипробуванні показали високий рівень однорідності за всіма ознаками ВОС-тесту і перевищували стандарт за показниками стійкості до біотичних і абіотичних факторів. На сортовипробувальних дільницях за умов дотримання науково обґрунтованої агротехніки урожайність нових сортів І33 сягає 10,0 і більше тонн зерна з гектара. В умовах зрошення стійкі до вилягання короткостеблов сорти Херсонська безоста, Херсонська 99, Росинка, Овідій, Кохана, Конка, Кошова, Соборна фрормують урожайність 9,0-10,1 т/га.

Численні дослідження і спостереження показують, що сорти закордонної селекції не витримують конкуренції з вітчизняними в умовах посушливого клімату Півдня України, поступаються за ознаками адаптивності і про- дуктивності, можуть бути використані лише як джерела та донори господарсько-цінних ознак у селекції для створення нового вихідного матеріалу.

Пріоритетним напрямом розробок $€$ підвищення адаптивного потенціалу генотипів без зниження досягнутого високого рівня продуктивності та якості зерна, якими володіють кращі сорти української селекції. Підвищення рівня адаптивних властивостей зимо- і посухостійкості, стійкості проти поширених на території України хвороб (борошнистої роси, бурої іржі, септоріозу, фрузаріозу колосу, кореневих гнилей тощо) позитивно впливатиме на реалізацію продуктивного потенціалу і за несприятливих умов сприятиме підвищенню нижнього рівня урожайності, що буде гарантувати одержання стабільно високих валових зборів зерна у різні за погодними умовами роки на великих площах посіву озимої пшениці.

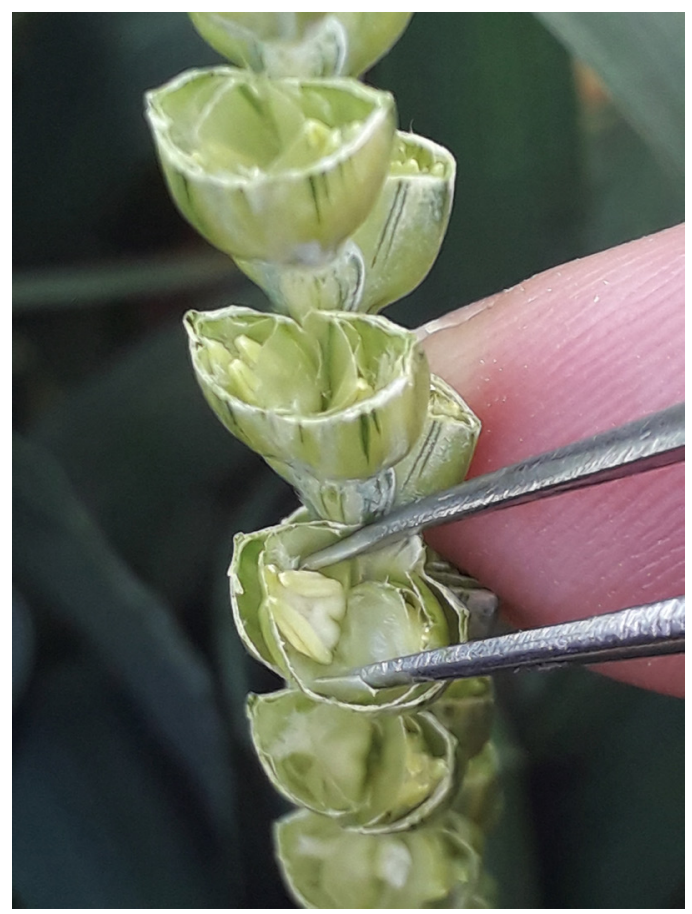

- Які генетичний потенціал сортів пшениці селекції Інституту зрошуваного землеробства та стійкість їх до лімітуючих чинників довкілля?

- Вагомим чинником стабілізації підвищення врожайності продовольчого зерна у сучасних умовах 
може бути лише у разі впровадження нових, високопродуктивних, конкурентоспроможних сортів з широкою агроекологічною пластичністю і підвищеними адаптивними властивостями до несприятливих та екстремальних умов середовища.

В Україні, як і в багатьох інших країнах, генетичний потенціал комерційних сортів озимої м'якої пшениці реалізується на недостатньому рівні. За даними вчених-селекціонерів, у державному сортовипробуванні він реалізується у середньому на $65,9 \%$, а стосовно максимального урожаю на державних сортовипробувальних дільницях - на 36,0\%. Це свідчить про великі можливості підвищення урожайності озимої пшениці за рахунок застосування досконалих, науково обґрунтованих технологій вирощування рослин, які дозволять реалізувати потенційні можливості новостворених сортів.

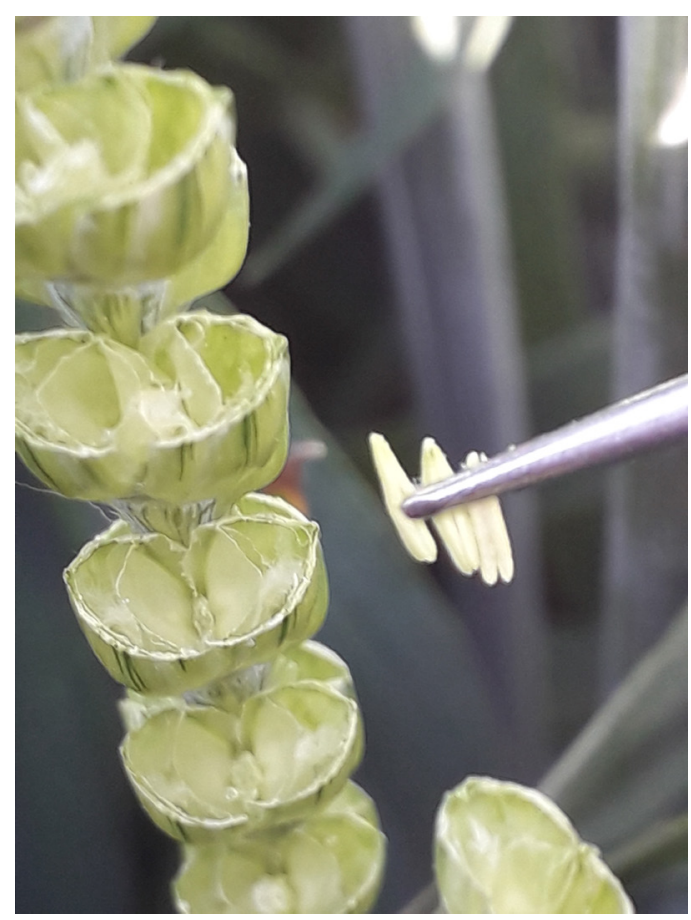

У різні роки провідними селекціонерами надавалась класифрікація пшениці м'якої озимої за генетичними особливостями. Перший тип - інтенсивні сорти з максимальним потенціалом урожайності, сильні за якістю зерна з висотою до 100 см, стійких до основних хвороб, із середнім та високим рівнями зимо- і посухостійкості. До них належать сорти: Херсонська безоста, Овідій, Кохана, Конка, Марія, які якнайкраще реалізують свій потенціал продуктивності на високих агрофонах за сприятливих умов, тому їх краще вирощувати за інтенсивними технологіями.

Другий - напівінтенсивні сорти з висотою рослин 100 см і більше. Відзначаються високою агроекологічною пластичністю, доброю регенераційною здатністю після перезимівлі, мають перевагу над сортами першого типу за стабільністю врожайності у разі розміщення їх після непарових попередників та за екстремальних умов пластичності щодо строків сівби. Це сорти селекції Інституту зрошуваного землеробства НААН України: Херсонська 99, Росинка, Благо, Ледя, Соборна, Кошова, Перлина Степу.

Третій тип - проміжний, або універсальний, тип сортів нашої селекції з комплексною стійкістю рослин до основних хвороб, з оптимальною висотою рослин 95-100 см, що забезпечує рівень урожайності 8,5-11,5 т/га, стійких до вилягання та несприятливих умов вирощування: Бургунка, Анатолія, Аквілегія, Херсонська Фортеця.

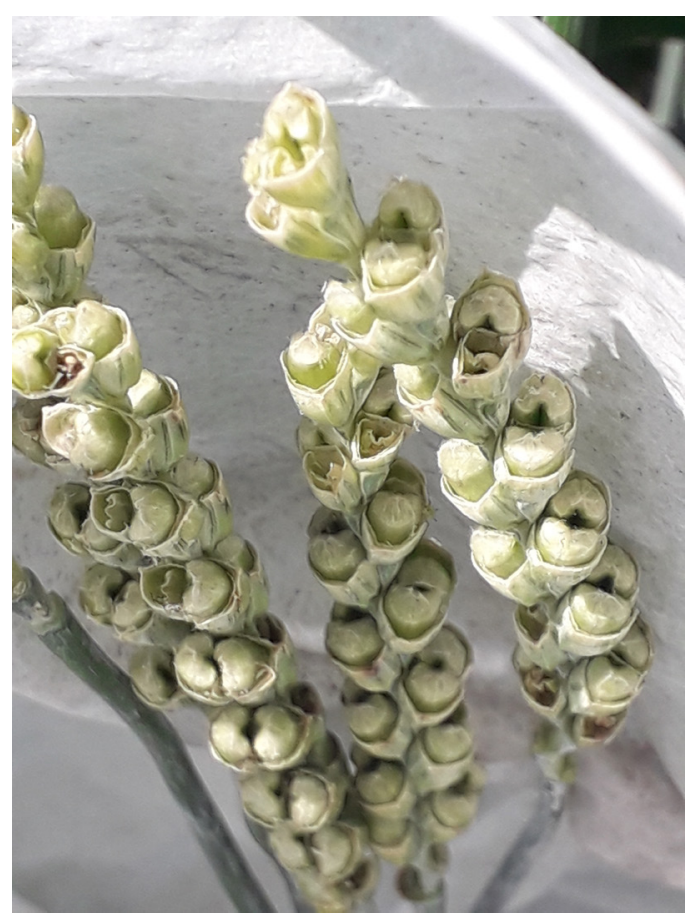

- Які Ви можете відзначити наукові напрями селекції пшениці озимої за умов зміни клімату у Південному Степу України?

- У Південному Степу України переважають роки з посушливими умовами і дефіцитом продуктивної вологи і період оптимальних строків сівби, тому у виробництві майже неможливо отримувати щорічно повноцінні сходи. Через це виникає необхідність сівби пшениці озимої у пізні строки (жовтень, листопад) після випадіння агрономічно суттєвих опадів. Тому створення сортів, придатних для пізніх строків сівби з коротким періодом яровизації, або сортів-дворучок, тепер дуже актуальне. Такі сорти характеризуються осінньою підвищеною продуктивною кущистістю: Херсонська безоста, Херсонська 99, Конка, Аквілегія.

Сорти-дворучки - це сорти альтернативного типу, здатні формувати продуктивне колосся як за умов пізньо-осіннього посіву, так і у зимові вікна. Вони значно перевищують за урожайністю як типові озимі, так і ярі сорти. Цим перспективним напрямом у селекції пшениці і займаються наші селекціонери, проводять вивчення кращих створених ліній. 


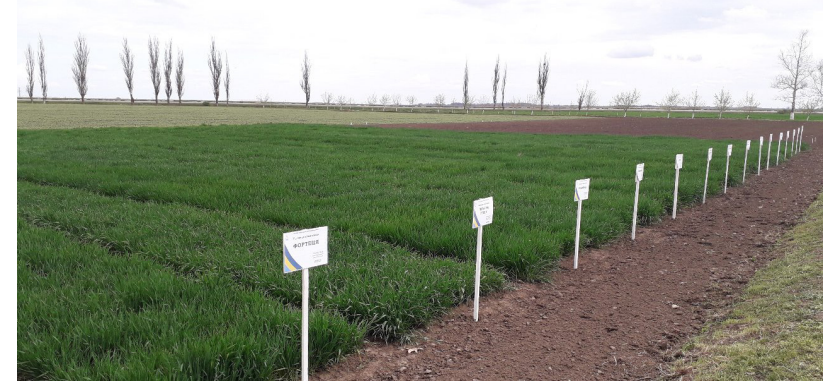

- Яке місце сортів пшениці твердої озимої селекції Інституту у перспективі відновлення вітчизняної переробної галузі?

- Високоякісні макаронні вироби можна виготовити тільки із зерна сортів пшениці твердої озимої та ярої. Оскільки більшість товаровиробників використовує для макаронів борошно пшениці м'якої озимої, це позначається на якості макаронної продукції, а саме знижується гатунок макаронних виробів.

Проблемою $є$ переробна промисловість, яка розвинута не досить. Зерна пшениці твердої озимої виробляється в Україні значно менше, ніж зерна пшениці м'якої озимої. А ціна на зерно твердої пшениці в 1,3-1,5 раза вища. Тому це одна із причин великого обсягу імпорту макаронних виробів.

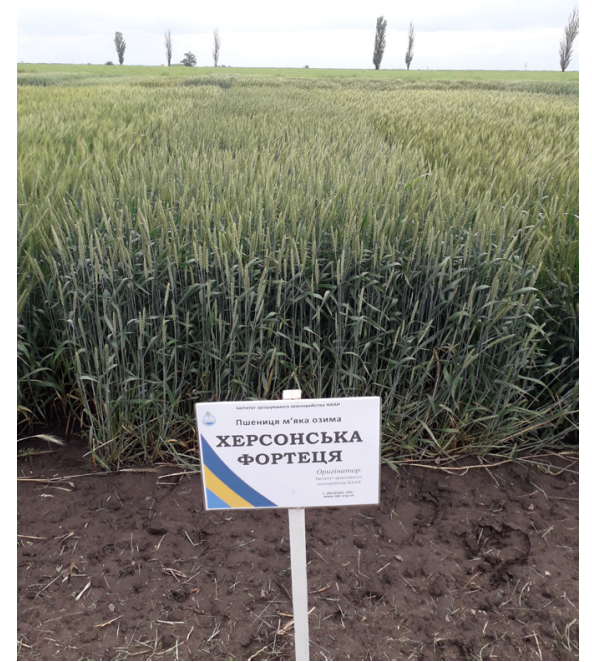

Сорти пшениці твердої озимої Інституту зрошуваного землеробства НААН України Дніпряна, Кассіопея, Андромеда відповідають вимогам стандартів на високоякісну продукцію. Потенціал урожайності - 7,5-9,0 т на зрошенні, вони стійкі до хвороб, мають підвищені морозо- і зимостійкість. 